\title{
WHO SPOKE THE MAGNIFICAT?
}

DR BURN's edition of the works of Niceta, the author of the Te Deum, has once more raised the question which forms the subject of this paper. Niceta wrote, among other things, a tract De Psalmodiae Bono, and in this he distinctly assigns the Magnificat to Elisabeth. His words are:-

'Ergo in euangelio inuenies primum Zachariam patrem magni Iohannis post longum illud silentium in hymni uice prophetasse. Nec Elisabeth, diu sterilis, edito de repromissione filio Deum de ipsa anima magnificare cessauit' (Burn, p. $76 \mathrm{f}$ ).

'Cum Elisabeth Dominum anima nostra magnificat' (Burn, p. 79).

Niceta, therefore, is to be added to the small group of textual 'authorities' which read in Luke i 46 et ait Elisabet where our

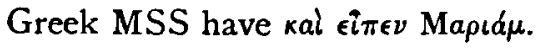

Strictly speaking, the evidence of Niceta does not add material weight to the testimony for 'Elisabeth'. The reading 'Elisabeth' is found in $a, b$ and $l^{*}$, i. e. in the leading Latin texts of North Italy, and also in the Latin of Irenaeus 235. These make up a typical 'European' group, just the company with which we should expect to find Niceta in agreement. Their united testimony shewed the reading 'Elisabeth' to belong to a very early stage of the European branch of the Old Latin version, and the accession of a fourth-century Father like Niceta cannot take us beyond this conclusion. At the same time I still think, as I wrote in Dr Burn's Introduction (p. cliii), that 'Niceta's authority may remove some of the more general objections to the unfamiliar reading. That the author of the Te Deum saw nothing incongruous in regarding the Magnificat as the utterance of Elisabeth shews that such an opinion is not incompatible with the strictest orthodoxy or with the fullest sense of the requirements of Christian worship.' I did not mean by these words that I thought Niceta a particularly expert biblical critic, but I do think his witness goes for something in the question of taste. There is a famous example of what I meant in another vexed 
question. The 'medical' interpretation of xá $\theta a \rho \sigma$ เs in Aristotle's definition of Tragedy has been held to be an unpoetical, and therefore an inadmissible, view. Against this it is enough to point out that an interpretation which was poetical enough for Milton is poetical enough for ordinary mortals. Similarly in the case of the Magnificat, a view of its origin which was seemly enough for the author of the Te Deum may be proved to be incorrect, but it is not open to the charge of being either an unseemly or an unworthy view.

It will probably be agreed by all who study the question that the actual occurrence of Helisabeth in Irenaeus 235 carries with it a very strong presumption that when we read in Irenaeus 185 exultans Maria clamabat pro Ecclesia prophetans'Magnificat...' the word Maria has been substituted by copyists for Helisabeth. The general sense of the whole passage is the same as in 235 , viz. that the true seed of Abraham exulted in the prophetic spirit to see the coming of the Christ who had been promised to the Fathers. Moreover, we know that on the preceding page (Irenaeus 184 ) an ancient Western reading has been corrected out of our present Latin text, for whereas the present Latin has Hic est filius meus for Matt. iii 16, the Oxyrhynchus fragment of Irenaeus, an almost contemporary witness, reads $\sigma \dot{v} \in i \dot{o}$ viós $\mu o v$. It is a pity that the fragments do not include the quotation from Luke i 46.

But the evidence of Tertullian is clear for 'Maria': Exultat Elizabeth, Ioannes intus impulerat; glorificat dominum Maria, Christus intus instinxerat (De Anima 26). This African testimony is borne out by $\ell$, and with these go all Greek and all Syriac texts of Luke i 46 . Such a consensus of authority is practically fatal to the claim of 'Elisabeth' to be considered the original reading; yet if 'Mary' were genuine the actual occurrence of 'Elisabeth' in the European branch of the Old Latin would be inexplicable. Now if the original text of the Gospel had

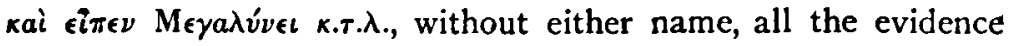
falls into line. On the one hand, many texts ascribed the Hymn to Mary on the ground of the supposed appropriateness of Luke $i 4^{8}$ to the mother of our Lord. On the other, the text which underlies the European Latin-I will venture still to add, with greater literary tact-perceived that the pronoun in Luke i 56 ('Mary remained with her') should refer to the person who utters 
the Hymn, and therefore that person must be Elisabeth. This point was evidently seized by the Syriac versions, for the Peshitta

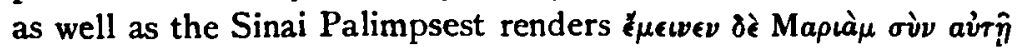
by 'Now Mary remained with Elisabeth'. But the Greek of i 56 has retained the tell-tale av่rî, a word which I think enough, even without the evidence of Irenaeus and Niceta, to shew that St Luke intended us to understand that the Magnificat was spoken by Elisabeth and not by Mary.

The substance of the preceding paragraphs forms the conclusion of the note upon Niceta's Biblical text which I wrote for Dr Burn's book. He very kindly allowed me thus to express my opinion, although I was unable to convert him to my view. Following my note comes a note by the Bishop of Salisbury, who is an unhesitating defender of the ascription of the Magnificat to the Virgin Mary. Some of his arguments are referred to below, but I mention the note here because on the textual question I am delighted to find myself in agreement with the Bishop. He says : 'I have been for some time of opinion that the best explanation of the various readings "Mary" and "Elizabeth" is that both are glosses, intended to clear up the sense of a phrase which some readers or scribes found ambiguous. The original reading then would have been simply xal $\epsilon i \pi \epsilon \nu . .$. 'The conclusions of a single scholar do not, of course, decide the issue; the testimony of the Bishop of Remesiana does not make 'Elisabeth' genuine, and the opinion of the Bishop of Salisbury does not make it and 'Mary' a gloss. But in a matter which does to some extent affect the feelings of many Christian worshippers I am anxious to shew that I am not defending a paradox out of mere perversity, and that the direct evidence for the ascription of the Magnificat to the Virgin is not so strong as might at first sight appear.

Let us go on then to ask the Bishop of Salisbury's question :

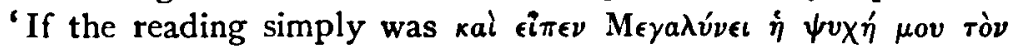
Kú to be supplied by the reader from the context?"

The answer falls into two parts. There is the question whether the Magnificat itself is more appropriate in the mouth of Mary or of Elisabeth; and there is the question whether the course of the conversation between the two Saints makes it more appro- 
priate to regard Luke $i 46-55$ as the continuation of the words of the previous speaker or as the reply of the other.

Let us take the second point first. The whole conversation, with the proper names, runs in skeleton as follows:-

Luke i 40 Mary ... entered into the house of Zacharias and greeted Elisabeth.

4I And it came to pass when Elisabeth heard the greeting of Mary the babe leaped in her womb, and Elisabeth was filled with a holy spirit,

42-45 And ... said, 'Blessed art thou among women ...'

46-55 And she said, 'My soul doth magnify the Lord ...'

56 Now Mary remained with her three months.

Does the literary habit of St Luke or the general march of the narrative suggest a change of speaker at $v .46$ ? I think not.

St Luke is quite remarkably fond of inserting xai $\epsilon i \pi \epsilon \nu$ or $\epsilon i \pi \epsilon \nu$ $\delta \epsilon \in$ between the speeches of his characters, without a change of speaker. This is often the case in the longer discourses of our Lord, where one parable or saying follows another without a break, e.g. Luke xV I I ( $\epsilon i \pi \epsilon \nu \delta \epsilon)$. We find this even in cases such

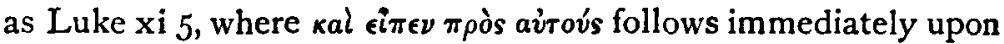
"He said to them, "When ye pray, say so-and-so"' '. In these instances, however, it may be said that the eimev marks a fresh source or a fresh section; but St Luke's practice is not confined to such cases. In at least three instances the $\epsilon i \pi \epsilon \nu$ or $\epsilon^{\prime} \lambda \epsilon \gamma \in \nu$ comes in the middle of what is represented as continuous discourse. I give them in full :-

Luke iv 23, 24. And he said unto them: 'Doubtless ye will say unto me this parable, "Physician, heal thyself: whatsoever we have heard done at Capernaum, do also here in thine own

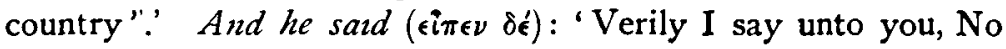
prophet ...'

Luke xviii I-6. And he spake a parable ... saying: "There was in a city a judge . . . and he said within himself, "Though I fear not God, ... yet ... I will avenge [this widow]".' And

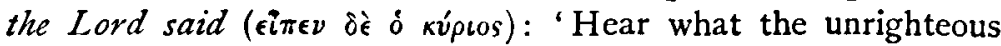
judge saith ....'

Luke xxi 9, 10. ' . . when ye shall hear of wars and tumults,

1 I do not count Luke xii 18 , because the rich fool is having a dialogue ( $\delta_{t \in \lambda} \lambda_{0}$ i-

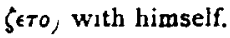


be not terrified : for these things must needs come to pass first ; but the end is not immediately.' Then said he unto them (rórє ' $\lambda \epsilon \gamma \epsilon \nu$ airroîs), ' Nation shall rise against nation. . . .'

The last instance is specially interesting from the point of view of the literary method of St Luke, for there is no question but that both verses form part of the same discourse and are addressed to the same audience. Moreover, in this case we actually possess the source of St Luke's words, viz. Mark xiii 7, 8. These verses are repeated almost verbally by $S t$ Luke, but he separates them

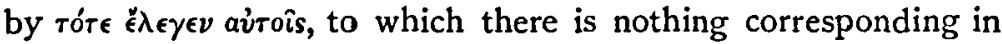
St Mark or in the parallel passage Matt. xxiv 6, 7. St Luke's little interpolation seems merely designed to throw a certain emphasis upon the words to which they are prefixed ${ }^{1}$.

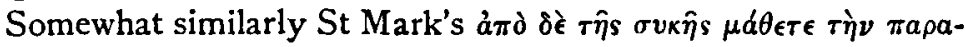

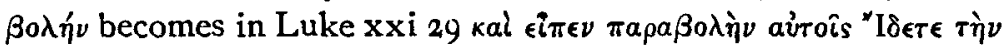

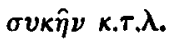

From these instances it will be seen at once that we have no reason to demand a fresh speaker from the occurrence of the words $\kappa$ ai $\epsilon i \pi \epsilon \nu$ in Luke i 46 . The verses $\mathrm{i} 42-45$ are Elisabeth's direct reply to Mary's salutation, mentioned in i 40 ; the following verses i 46-55 (i.e. the Magnificat itself) are not conversation but pious meditation: the transition from one to the other is marked by kai $\epsilon i \pi \epsilon \nu$, indicating not a change of speaker, but of the mode of speech.

This usage is by no means confined to St Luke's Gospel : good instances are common enough elsewhere. Thus in John i $50 \mathrm{f}$, "Jesus answered and said unto him [i.e. Nathanael], "Because I said ... thou shalt see greater things than these." And he saith unto him, "Verily, verily ... ".' Here the two sayings are absolutely continuous and addressed to the same individual. And again in Mark vii 8, 9, we read (our Lord is speaking): "Ye leave the commandment of God, and hold fast the tradition of

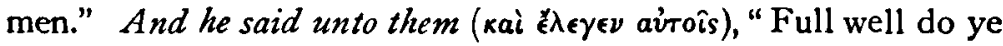
reject the commandment of God ...".' But indeed we need not

1 The above instances are all taken from our Lord's sayings. It is only natural that most of the examples should occur in $\mathrm{His}$ words, because $\mathrm{He}$ is the chief speaker all through. But the same way of writing is found in the story of the Penitent Thief (Luke xxill 42). En revanche, a speaker in a real dialogue is sometimes not formally introduced each time by the Evangelist, as in Luke vii $4^{I}$. Both in vii $4^{1}$ and in $x \times i$ io most Western texts avoid the difficulties. 
go further than I Kings xxii, the very same chapter to which the Bishop of Salisbury refers us. In $v .28$ we read, 'And Micaiah said, "If thou return at all in peace, the LORD hath not spoken by me." And he said, "Hear, ye peoples, all of you"' '.

But the Bishop of Salisbury urges that if the Magnificat were not spoken by Mary, 'the question of Elizabeth and her glowing words of address to her cousin received, so far as we know, no answer or acknowledgement.' It seems to me that this is rather a prosaic way of looking at the tale as told by St Luke. I cannot see that the 'question of Elizabeth' is a genuine interrogation, or that Mary had any answer to give. 'Whence is this to me, that the mother of my Lord should come unto me?' Well, but is the Magnificat any answer to this question? I fully recognize that St Luke gives us the account of a conversation, and also that a 'salutation' requires an acknowledgement. But the whole of Elisabeth's words are the acknowledgement of Mary's salutation, which is expressly mentioned in $v v .40$ and $4 \mathrm{I}$.

If we assign the Magnificat to Elisabeth, the 'conversation' of the two holy women has a striking parallel in Luke ii 25-35, i. e. the 'conversation' of Mary and Simeon. In both cases Mary's interlocutor is said to have a holy Spirit, in both cases the whole of the words recorded is assigned to the interlocutor, and the words themselves consist partly of pious meditation, partly of words addressed exclusively to Mary.

We have now to consider whether the actual contents of the Magnificat are specially appropriate to Mary. It is not conclusive to point to $v \cdot 4^{8}$, for the custom of calling the Mother of our Lord 'the Blessed Virgin' is derived directly from the wording of this verse. I am surprised to find the Bishop of Salisbury saying that 'the word paxáptos is not so common as to be used in such a connexion without emphasis'. Surely paxapia is almost a technical term for a 'happy mother'. Either

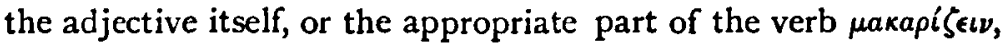

1 The question at issue is one of style, not of authenticity, so that the mere occurrence of the last clause in the Massoretic Text is sufficient for my purpose. They occur again in a Chron. xvili 27. I firmly believe them to be original; but they are omitted in the Greek of 3 Regn xxii 28 , and the words $A$ nd he satd are omitted in the Greek of 2 Chron. xvii 27 , probably because they seemed unnecessary. There are several instances of arbitrary curtailment in the Greek of 3 Regn. $x_{11}$, c. g. at the beginning of $v .27$.

VOL. VII. 
is the proper word to use in congratulating a mother or a grandmother ${ }^{1}$. By a kind of oxymoron, used to produce an unexpected effect, paxapia is predicated of the barren or the unmarried (Wisd. iii I3, Luke xxiii 29, I Cor. vii 40), but these three passages are almost enough by themselves to prove that the word was ordinarily used of the happiness of mothers in their children.

There is an obvious example of this in Luke xi 27. A still more instructive instance is to be found in Gen. $x \times x \times 13$, the Greek of which has, I believe, helped to colour the wording of Luke $\mathrm{i}_{4} 8$. At the birth of Asher, who was counted as a child

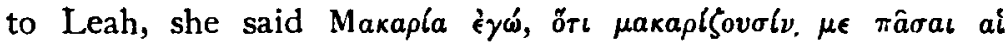
yvvaikes. I cannot help believing that these very words were in St Luke's mind, and that just as Leah is here making a play of words on the name of Asher, so Luke i 49,50 is a prophetic reference to the name John which was about to be given to the son of Elisabeth. Fohn means 'Jahwe has shewn mercy'; it is therefore exceedingly appropriate that Elisabeth should say: 'They will call me happy like Leah, and therefore the son that is to be born will derive his name from the Holy Name of the God of Israel and at the same time commemorate His mercy.' Somewhat similarly Zacharias, the father of John, when filled with a holy Spirit. speaks in i 72 of the 'mercy' of the Lord God of Israel, and in the following verse we may detect in the mention of the 'oath' which He sware to Abraham an allusion to the name of John's mother, Elisabeth.

The rest of the Magnificat, so far as it can be said to be specially appropriate at all, fits Elisabeth's position better than Mary's. 'My soul doth magnify the Lord ' is re-echoed in i 58 , where at the birth of John Elisabeth's kinsfolk heard that the Lord had magnified His mercy towards her. That 'her spirit

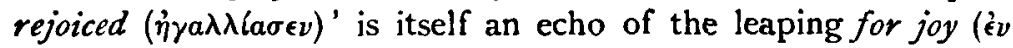

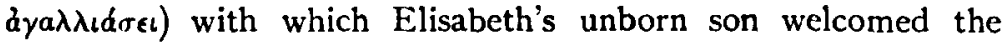
Mother of his Lord. The words 'For he hath regarded the lowliness of his handmaiden ' are a direct adaptation of Hannah's prayer in I Regn. i I 1 , and therefore more appropriate in Elisabeth's mouth than in any other.

That the latter part of the Magnificat is really appropriate

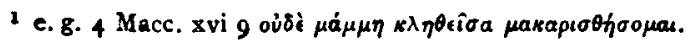


either to Mary or to Elisabeth in the historical setting of St Luke's narrative is a paradox which I am not prepared to maintain, but it is certainly not more appropriate to Mary than to Elisabeth. It consists of adaptations of Old Testament phrases taken from various parts of the Bible ${ }^{1}$, the general effect being much the same as Hannah's Song, itself a very curious psalm for the occasion of its utterance. But the Septuagint lay before St Luke as it lies before us, and the wording of Hannah's Song is enough to explain the mention of Dynasts and Thrones, of the Hungry and the Rich. And in the LXX, as indeed the Bishop of Salisbury points out, Hannah's speech to Eli is immediately followed by Hannah's Song with only kai $\epsilon i \pi \epsilon \nu$ in between; I cannot but think that this was in St Luke's mind when he placed the Magnificat immediately after Elisabeth's reply to Mary's greeting. In direct imitation of I Regn. ii I St Luke inserts kai $\epsilon i \pi \epsilon \nu$ between the two parts of Elisabeth's utterances.

At the conclusion of my note in Dr Burn's edition of Niceta I expressed the opinion that the Magnificat was more appropriate in the mouth of the matron Elisabeth than in that of the Virgin Mary, and I ventured to adapt the famous phrase of St Ignatius (Magnes. $\$$ ) in which Jesus Christ is called God's Word that came forth from Silence (aủrov $\Lambda$ óyos àmò $\left.\Sigma_{\iota} \gamma \hat{\eta} s \pi \rho o \in \lambda \theta \dot{\omega} v\right)$. My view that the Magnificat is intended by St Luke to be the Song of Elisabeth may be mistaken; but I cannot think that to be a serious error in orthodoxy, which I share with Irenaeus, or a serious error in taste, which I share with the author of the Te Deum ${ }^{2}$.

F. C. BURKITT.

I e.g. Luke $i 54^{\mathrm{a}}$ is taken from Isaiah xli $8 \mathrm{f}(\mathrm{LXX})$ : notice the use of dytr$\lambda a \mu \beta a ́ v \epsilon \sigma \theta a$.

'It was only after this article was in tvpe that I was able to read Professor Harnack's brilliant article, called Das Magnificat der Elisabet, in the Sitzungsberichte of the Berlin Academy for 1900, pp. 538-556. Harnack's general conclusions agree almost exactly with the view I have ventured to defend. 'So schneb er [Lukas] enfach. kaì Girøv. Dieses konnte zu der Annahme verführen, als trete ein neues Subject ein, und hat leider sehr frahe zu hhr gefahrt : in den Hauptstrom der Uberlieferung wurde Mapıá $\mu$ aufgenommen; nur auf einer schmalen Lıne erhuelt

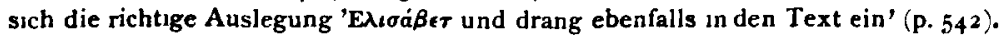
The chief difference between Harnack's interpretation of the evidence and that given aboie concerns Irenaeus 185 . Professor Harnack thinks that St Irenaeus really read 'Mary' in Luke $i 4^{6}$, and that 'Elisabeth' In Irenaeus 235 is due to the Latin translator. But I venture still to adhere to my own view and to believe that Irenaeus regarded Elisabeth as a type of the ancient Jewish Ecclesia prophesying by a Divine Spirit about the Christ. 